\title{
IDENTIFICATION OF FACTORS CAUSING DRIVER'S DISTRACTION IN OMAN
}

\author{
Muhammad Ashraf Javid* Mustafa Yousif Al-Neama \\ University of Nizwa, Department of Civil and Environment Engineering, Oman
}

In recent years the economic and infrastructure development have led to increase the number of private vehicles on the roads in Oman. The increased motorized traffic tends to increase the roadside accidents that results in fatalities and injuries. To ensure safe mobility of the citizens, it is very important to evaluate the underlying factors that contribute towards the occurrence of accidents so that proper countermeasures can be developed and implemented. The main objective of this study was to identify the most significant driver's distraction factors through a questionnaire survey and suggest some policy measures. The designed questionnaire was consisted of personal and driving attributes, and potential internal and external factors that cause distraction to the drivers. This questionnaire survey was conducted at some feasible locations in Muscat and Nizwa city with drivers of different vehicles. The results of 252 collected samples showed that the use of mobile phone, eating while driving and presence of passengers in vehicle are the most significant internal distraction factors. Significant external factors included looking at the scenic elements, advertisement boards and other drivers. It was predicted that cell phone, interaction, and disturbance-oriented factors are significant determinants of driver's propensity to be involved in an accident. This study proposed some behavioral intervention techniques that need to be considered for the improvement of traffic safety in Oman.

Key words: Traffic safety, Driver's distraction, Questionnaire survey, Structural equation modelling, Oman

\section{INTRODUCTION}

There is increase in the use of private vehicle due to rapid increase in motorization and infrastructure development. There are almost 230 vehicles per 1,000 people in Oman that is much higher among middle-income countries, and motorization rate is about $26 \%$ from 2000 [01]. In the absence of proper public transportation system the high use of private vehicle results more traffic on the road infrastructure involving high rate of accidents. According to world health organization (WHO) report since 2000 , nearly 10,000 people lost their lives in crashes in Oman and more than 110,000 have been injured [02]. Same statistic shows the 25.4 deaths per 100,000people that put Oman as the second highest rate of deaths in Gulf Cooperation Council (GCC). Statistics from Royal Oman Police(ROP) shows that, the number of accidents in Oman came across different stages; at the middle 80's the number of accidents reaches a peak of more than 16000 accidents in 1985, then it start decreasing in the 90's reaching an average of 11000 accidents [03]. After 90 's it starts gradually to decrease reaching the lowest number of accidents in the last year with around 6000 accident. In 2015 the number of fatalities and injuries drops by more than $30 \%$ compared to the number of injuries and fatalities in 2013 [03]. According to Islam and Al-Hadhrami [01] in Oman, almost $70 \%$ of the road traffic accidents (RTAs) happened to drivers aged 17-36 years. Over speeding is one of the main cause of road traffic accident (50\%), followed by negligence or careless driving $(29 \%)$. Human factors are responsible for almost $98 \%$ of accidents. Al-Reesi et al. [04] reported that crashes are predominantly occurring on single highway and being mainly caused by over speeding among young drivers. They also mentioned the strongest factors of fatality are run-over type crashes, being male, crashes with motorcycle and bicycles, and early morning crashes. There can be many reasons of high accident rate and may include poor infrastructure, distracted driving and driver's behavioral issues [05].

Distracted driving is defined as specific type of inattention that occurs when drivers divert their attention from the driving task to focus on some other activity. Distraction while driving can be separated into three groups: visual, manual, and cognitive. Visual distraction involves taking one's eyes off the road while manual distraction involves taking one's hands off the steering wheel. Cognitive distraction occurs when taking mind off the road. Regan et al. [06] provide another comprehensive classification of driver's distraction factors i.e. internal and external distraction factors. In-vehicle or internal distraction factors include mobile phone use, control of navigation/ entertainment systems, and conversation with passengers, eating or drinking, and smoking. External distraction factors include looking at advertisement signs and labels, traffic signs, landscape, destination or address search, other vehicles, pedestrians and incidents. Yannis et al. [07] showed that the use of mobile phone in combination with high speed and adverse weather conditions increases the probability of accidents in case of unexpected events. Mobile phone use appears to be the most critical in-vehicle distraction factors and regarding external distraction sources, advertising signs are associated with increased driver distraction but not 
with accident risk [08-09]. Foss and Goodwin [10] state that electronic device use, adjusting vehicle controls and grooming are the most significant distraction factors, and distracted driver behaviors are less frequent in the presence of other passengers. However, loud conversation and horseplay were quite common in the presence of multiple peer passengers. According to Simson-Morton et al. [11] eye glances away from the forward roadway involving secondary activities increased the likelihood of crashes and near crashes (CNC). The longer the duration of eye glance away from the road the greater is the risk of having accident regardless of the secondary task. Similarly, obligations to attend work calls and overconfidence of the drivers to drive while talking/texting are critical areas to intervene in and have large public health implications [12].

Distracted driving is growing on Oman's roads and if you look on roads, drivers are drifting or swerving across lanes, stopping at green light and running at red ones, driving outside their lanes without looking, and narrowly missing other cars and/or pedestrians. All this happen, because they are busy in other activities while driving such as texting or talking on phone, eating and drinking, dealing with unrestrained children in the car, or a combination of several distracted activities. It has been observed that children are frequently allowed to sit on front seat and drivers are busy with them in talking and playing while driving. Such drivers influence other road users as their mind is not completely focusing on the driving task and may cause fatal crashes. Driver's distraction is one of the main reasons for high accident rate in Oman. Earlier studies at local level have examined various drivers' characteristics in relation to aberrant driving behaviour and crash involvement such as demographic attributes and personality traits [04, 13]. In above-mentioned studies, mobile phone usage appears to be common and significant in-vehicle factor whereas outside vehicle factors include looking at advertisement signs and other vehicles. However, driver's characteristics and driving culture differ from region to region as traffic enforcements and infrastructure development conditions vary. The local drivers behave accordingly, as what they perceive from the society, legal restraints and provided infrastructure. There is a sheer need to investigate the causal relationship between factors of distracted driving and driver's propensity to be involved in an accident considering social and cultural circumstances of Oman. Therefore, the main objective of this study is to design a questionnaire survey for the collection of the required data, and diagnose significant factors resulting driver's distraction and accidents in the local context of Oman.

\section{DATA COLLECTION METHODS}

This section presents background of data collection methods.

\section{Questionnaire Design}

A detailed questionnaire was designed in this study, consisting of three parts as presented in appendix. First part included information of personal and driving attributes of the drivers e.g. age, gender, education, profession, nationality, marital status, driving experience, type of vehicle driving, etc. In second part of questionnaire, several statements were designed on potential internal and external distraction factors. All these items were designed considering the available literature regarding distracted driving behavior [06, 08-09, 14] and local attitudinal and behavioral aspects of driving in Oman. The main statements were on those activities that drivers generally do while driving e.g. cell phone use, eating, interaction with other in-vehicle passengers, eating/drinking, looking at signs and advertisement signs, and involvement in control of entertainment devices. All statements in this part were designed seeking the observed driver's behavior on the roads and their risk in resulting accidents. These questions were evaluated using a five point Likert scale (1: never, 2: rarely, 3: sometimes, 4: very often, and 5: always).A five-point scale was selected seeking the reliability of the data and a questionnaire survey with drivers having different social and economic status. Few questions were asked in 3rd part of the questionnaire related to policy aspects of traffic accident reduction in Oman. These questions were evaluated on different variables or scale considering their nature and suitability as presented at the end of appendix.

\section{Survey and Sampling}

This questionnaire survey was conducted with the drivers of private cars, taxi, bus and truck at different locations in Muscat and Nizwa City. Before conducting the actual survey, the designed survey form was tested with few drivers in order to ensure the appropriateness and correctness of the designed items. It also assured us whether the questionnaire items are understandable for the drivers with different literacy level. The questionnaire was revised after the results of initial survey. The drivers were selected randomly at each location and questionnaire forms filled by interviewing each driver. Before taking interview, the drivers were introduced about the objectives and contents of questionnaire. This survey was conducted with the help of university undergraduate students. Target sample size in this study was decided considering the convenience of conducting survey and analysis methods to be used i.e. structural equation modeling. A low response rate was observed at selected locations because many drivers did not agree to answer the questions citing different reasons. The total collected samples were 265; however, 13 samples were discarded due to incomplete and/or mistakes in the filled questionnaire. Therefore, data of 252 samples was used in further analysis. 


\section{DATA ANALYSIS}

\section{Distribution of Driver's Socio-Demographics}

Table 1 presents the distribution of respondent's socio-demographics. Almost $80 \%$ of the drivers are male. This is due to presence of some taxi, bus and truck drivers in the sample, as women do not drive commercial vehicles in Oman. The women drive only personal cars for their own and/or family travel. Most of the drivers have bachelor or above education. Almost $73 \%$ of drivers have age between 20-40 years and it can be said that most of them are belong to young age group. Most of the target drivers are students and employees of various organizations. Taxi, bus and truck drivers only account for $20 \%$ of the sample. Almost $48 \%$ drivers have driving frequency between $1-2$ hours and $19 \%$ drive for $3-4$ hours per day. In driving experience, $22 \%$ have $1-2$ years, $18 \%$ 3-4 years, $8 \% 4-5$ years and $52 \%$ more than 6 years.

Table 1: Descriptive statistic of driver's socio-economic demographics (SEDs)

\begin{tabular}{|c|c|}
\hline SEDs & Distribution (\%) \\
\hline Gender & Male (80), female (20) \\
\hline Marital status & Single (50), married (50) \\
\hline Age (years) & $\begin{array}{c}\text { Under 20 (5), 20-30 (52), } \\
\text { 31-40 (21), 41-50 (16), } \\
\text { more than 50 (6) }\end{array}$ \\
\hline Occupation & $\begin{array}{c}\text { Student (37), employee (51), } \\
\text { businessman (5), other (7) }\end{array}$ \\
\hline Driving & $\begin{array}{c}\text { 1-2 years (22), 3-4 years (18), } \\
\text { experience } \\
\text { Type ors (8), vehicle } \\
\text { more than 6 years (52) }\end{array}$ \\
\hline $\begin{array}{c}\text { Private car (80), taxi (12), } \\
\text { bus (7), truck (1) }\end{array}$ \\
\hline Driving frequency \\
per day & $\begin{array}{c}\text { 15-30 min (15), 1-2 hours (48), } \\
3-4 \text { hours (19), } \\
\text { more than 4 hours (18) }\end{array}$ \\
\hline
\end{tabular}

\section{Distribution of Response on Distraction Factors}

Figure 1 shows the distribution of driver's response on a five point Likert scale (1: never to 5: always) against various internal and external distraction factors. Most of the drivers have habit of performing other activities while driving with varying frequency. Almost $50 \%$ of the drivers use their phone sometimes, very often or always to make hand call while driving which shows high trend of using cell phone in driving. The trend of making phone call using headphones or Bluetooth is less as compared with handheld phone calls. Figure 1 shows that most of the drivers do texting while driving either rarely or more. Most of the drivers adjust the tape recorders or $\mathrm{mp} 3$ and eat or drink during driving either occasionally or always. According to response distribution, only few drivers do smoking while driving, whereas most of them have inter- action habit with other passengers sitting within the vehicle. In external distraction factors, only 20 drivers said that they do not focus on advertisements along roadside while driving whereas all other 196 drivers do observe such outside features with different frequency. Most of the drivers reported that bright light at night of the opposing vehicles disturbs them. Only $50 \%$ of the drivers use social network while driving. Some of the drivers get distracted due to sudden overtaking of police vehicles. The presence of children on the back seat also diverts the attention of drivers. Most of the drivers have observed other drivers using their cell phone while driving. These results show that drivers perform various activities with different frequency while driving and these activities include in-vehicle and out-of-vehicle activities. The most commons are use of cell phone, eating or drinking and looking outside while driving. It is said that these activities can result in driver's in-attention from driving task and consequently accident may happen.

\section{Distribution of Response on Traffic Safety Aspects}

According to the survey results, almost $14 \%$ of the participants reported that they have involved at least in one crash due to the use of mobile phone while driving and $70 \%$ of the participants said that they know someone (other drivers) involved at least in one crash while using mobile phone. Survey results show that $43 \%$ of the participants believe that over speeding is the main cause of accidents in Oman. While $37 \%$ participants choose using mobile phone $14 \%$ choose wrong overtaking, $4 \%$ choose fatigue and stress and $2 \%$ choose road condition as the main reason of accidents. Figure 2 shows the response of drivers on some traffic safety aspects. According to this distribution, majority of the participants agreed that use of mobile phone while driving increases the chances of having an accident. It means people have started realizing that use of mobile phone can leads to fatal car accidents. Around $50 \%$ strongly agreed that the availability of a good quality public transport system would help in reducing the accident rate in Oman.

\section{Structural Equation Modelling}

The structural equation modeling is well-known multivariate analysis tool used in various research fields. Its usage has become popular in transportation research. It involves development of measurement model using factor analysis techniques. A measurement model may include several observed variables or indicators and unobserved or latent variables. Measurement models can be combined to develop a structural model. In this paper, initially a factor analysis was conducted on driver's response on distraction statements. Factor analysis is a statistical technique use by researchers in examining the covariance among a set of observed variables in order to group them in the form of their latent or unobserved variables. Latent variables can be used to predict their influence on behavioral variables. 
Two types of factor analysis are available i.e. exploratory factor analysis (EFA) and confirmatory factor analysis (CFA). The choice of using EFA or CFA depends on the design of questionnaire items and their related hypothesis. In this study EFA technique was used as preliminary step to construct the structural model of driver's distraction factors.

\section{Factor Analysis}

An EFA was conducted using maximum likelihood method and varimax rotation. This factor analysis resulted in three factors. These factors were named considering the nature of their associated observed variables i.e. Cell phone oriented (CPO), interaction oriented factors (IOF) and disturbance oriented factors (DOF) as presented in Table 2. The observed variables with higher factor loadings have more influence in explaining the corresponding extracted factor. First factor of CPO mainly includes variables of driver's frequency to use mobile for different purpose (e.g. making calls, texting and checking social websites). The IOF factor consists of observed variables related to drivers interaction with the different in-vehicle elements (e.g. with other passengers, entertainment devices). Third factor of DOF includes distraction elements that tend to disturb the drivers during driving. To check the reliability of extracted factors, the Cronbach's alpha values were also calculated. A higher value of Cronbach's alpha shows high consistency among respondents in evaluating the observed variables of that factor. It was originated by Lee Cronbach's in 1951 in order to provide method for measuring the internal consistency of a test or scale as a number between 0 and 1 [15]. Comparing computed values of Cronbach's alpha with recommended value it is said that the extracted factors are acceptable in predicting the driver's behavior.

\section{Structural Model of Driver's Distraction Factors}

A structural model was developed using results of factor analysis as shown in Figure 3 . An endogenous observed variable was defined as 'accident propensity with use of mobile phone while driving (use of mobile phone while driving increases the chance of having an accident)' on a five point ordinal scale. Some observed variables on driver's personal and driving information were also included in the model to know their correlations with the driver's accident propensity with use of mobile phone while driving. Only significant variables are reported here and defined as dummy variable i.e. 1 if married otherwise 0,1 if male otherwise 0,1 if driver of private vehicle otherwise 0 , and 1 if reason of accident is mobile usage otherwise 0 .

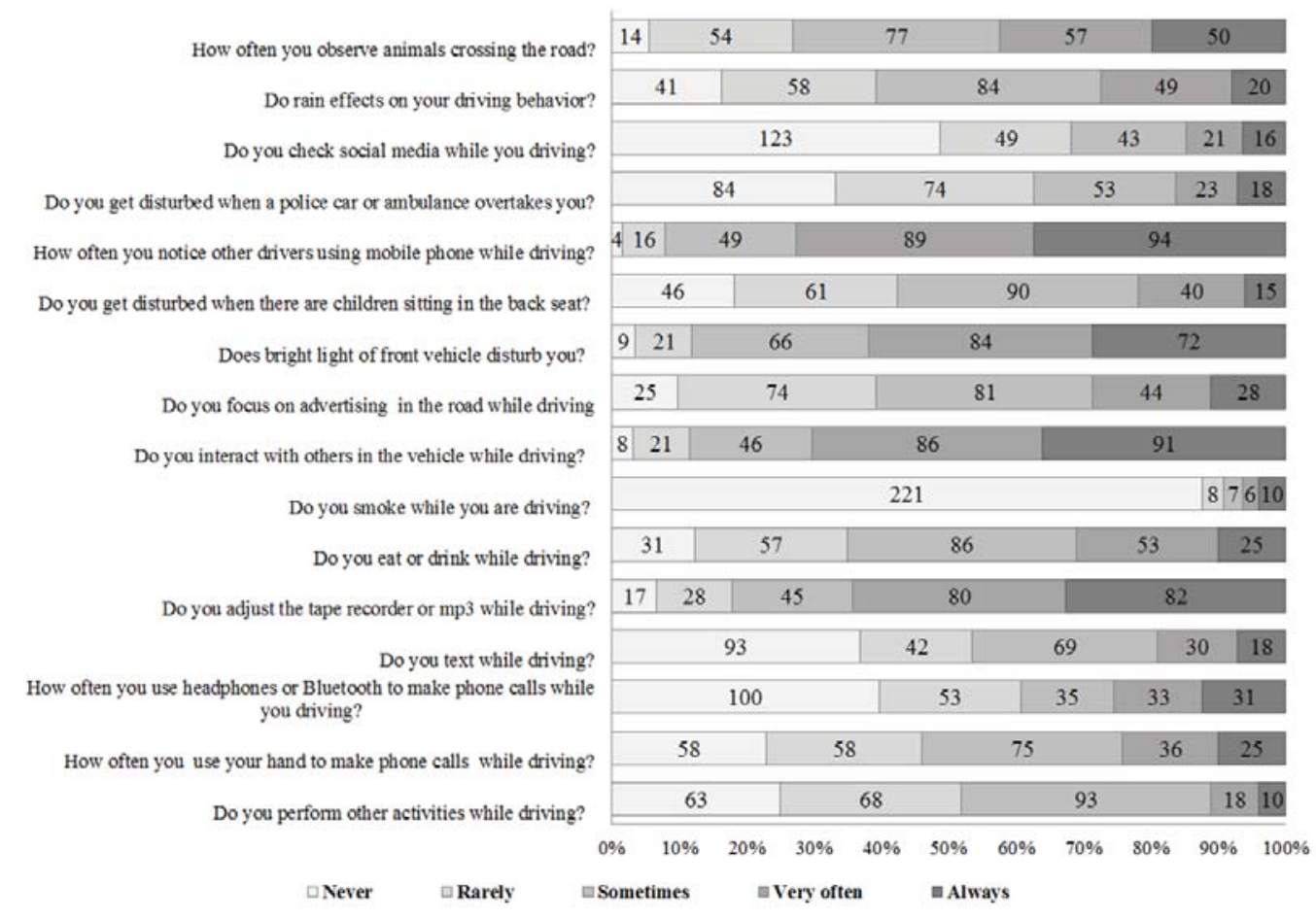

Figure 1: Distribution of response on driver's distraction factors 


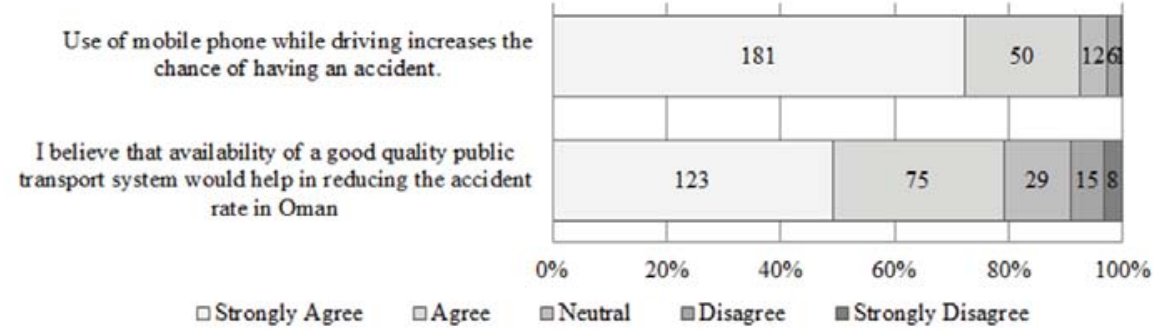

Figure 2: Response on various driving and traffic safety aspects

Table 2: Rotated factor loadings for extracted factors

\begin{tabular}{|c|c|c|c|c|}
\hline \multirow[b]{2}{*}{ Observed variables or indicators } & \multicolumn{3}{|c|}{ Factor loadings } & \multirow[b]{2}{*}{$\begin{array}{l}\text { Factor } \\
\text { Mean }\end{array}$} \\
\hline & $\begin{array}{c}\text { Cell Phone } \\
\text { Oriented } \\
\text { (CPO) }\end{array}$ & $\begin{array}{c}\text { Interaction } \\
\text { Oriented } \\
\text { factors (IOF) }\end{array}$ & $\begin{array}{c}\text { Disturbance } \\
\text { Oriented } \\
\text { Factors (DOF) }\end{array}$ & \\
\hline $\begin{array}{l}\text { How often you use your hand to make phone calls } \\
\text { while driving. (CPO-1) }\end{array}$ & 0.818 & -- & -- & \multirow{4}{*}{2.78} \\
\hline Do you text while driving? (CPO-2) & 0.809 & -- & -- & \\
\hline Do you check social media while you driving? (CPO-3) & 0.657 & -- & -- & \\
\hline Do you perform other activities while driving? (CPO-4) & 0.572 & -- & -- & \\
\hline $\begin{array}{l}\text { Do you interact with others in the vehicle while driving? } \\
\qquad \text { (IOF-1) }\end{array}$ & -- & 0.633 & -- & \multirow{4}{*}{3.38} \\
\hline $\begin{array}{l}\text { Do you adjust the tape recorder or mp3 while driving? } \\
\text { (IOF-2) }\end{array}$ & -- & 0.631 & -- & \\
\hline Do you eat or drink while driving? (IOF-3) & -- & 0.517 & -- & \\
\hline $\begin{array}{l}\text { Do you focus on advertising in the road while driving? } \\
\qquad \text { (IOF-4) }\end{array}$ & -- & 0.504 & -- & \\
\hline $\begin{array}{l}\text { Do you get disturbed when there are children sitting in } \\
\text { the back seat? (DOF-1) }\end{array}$ & -- & -- & 0.690 & \multirow{4}{*}{2.87} \\
\hline $\begin{array}{c}\text { Do you get disturbed when a police car or ambulance } \\
\text { overtakes you? (DOF-1) }\end{array}$ & -- & -- & 0.567 & \\
\hline Does bright light of front vehicle disturb you? (DOF-3) & -- & -- & 0.520 & \\
\hline Do rain effects on your driving behaviour?(DOF-4) & -- & -- & 0.419 & \\
\hline Cronbach's Alpha & 0.826 & 0.681 & 0.581 & \\
\hline
\end{tabular}

Figure 3 shows that most of the defined structural relationships are significant either at $1 \%, 5 \%$ or $10 \%$ level of significant. The significant structural relationship is positive between CPO and accident propensity with use of mobile phone while driving. This structural relationship predicts that the drivers who use mobile more frequently for different purposes have more chances to be involved in an accident. The positive structural weights of IOF and DOF with 'accident propensity with use of mobile phone while driving' variable depict that people who get engaged themselves in in-vehicle interaction, and get disturbed due to external factors have more propensity of being involved in accident. In other words, drivers who do involve in more activities at one time have more chances to experience crash. Yannis et al. [07] also report similar results that drivers who involved in multiple activities have more likelihood of an accident. All the structural relationships are positive between policy variables and defined driver's demographics. It implies that male, private vehicle driver and married drivers think that the use of cell phone increases the probability to be involved in an accident. The values of goodness of fit parameters are also reported at the bottom of Figure 3 . The permissible values for parameters of goodnessof-fit of a structural model are: ratio of chi-square to the degree of freedom (X2/DF) is less than 5 , and goodness of fit index (GFI), adjusted goodness of fit index (AGFI), and comparative fit index (CFI) are greater than 0.90, root mean square error adjusted (RMSEA) value is less than 0.08 and root mean square residual (RMR) is less than 0.08 . By comparing the values of goodness of fit parameters with permissible values, it is said that the 
developed structural model has reasonable fit in explain the driver's distraction behavior related to propensity of accidents.

\section{CONCLUSIONS AND IMPLICATIONS}

This study attempts to diagnose the significant factors of driver's distraction in Oman. The survey results showed that more than $70 \%$ of the drivers have the habit of performing other activities while driving and about $60 \%$ of them use their cell phone for different purposes with varying frequency. Most of the drivers have the habit of interacting with other passengers and controlling the entertainment facilities. They also look frequently on outside advertisement boards and get disturbed due to sudden overtaking of police vehicles, bad weather and bright light of opposing vehicles. These results imply that such activities cause distraction to the drivers and consequently results in accidents on the roads. The results of structural equation modeling reveal that cell phone, interaction, and disturbance-oriented distraction factors are significant determinants of driver's probability to be involved in an accident. There is good reliability of the developed model in determining the driver's distracted behavior in relation to traffic accident occurrence. It is found that in-vehicle distraction factors have more influ- ence, which is same as found in other studies results [08, 14]. Driver's marital status and gender are also significant determinants of their probability to experience an accident. It is suggested that there is a need to change driving habits of people in order to reduce distracted driving. This can be done through some training and educational programs that should focus on behavior modification. Such programs must be followed by heavy enforcement especially on the use of cell phone during driving, over speeding and wrong overtaking. Traffic safety policies also need to be developed and enforced regarding sitting of children on front seat and related restraints (e.g. fasten the seat belt). In addition the above policy measures, there is also a need to integrate some physical measures. For example, development of public transport in feasible areas may help in reducing the use of private vehicle, and as a result, there would be reduction of accidents. This research focused on various internal and external distraction factors with a small sample size, and extracted findings may have limitations in their implications. It is recommended to consider mobile phone use and over speeding behavior in detail in future studies. Future studies should also focus on different segments of drivers market that usually require large sample size.

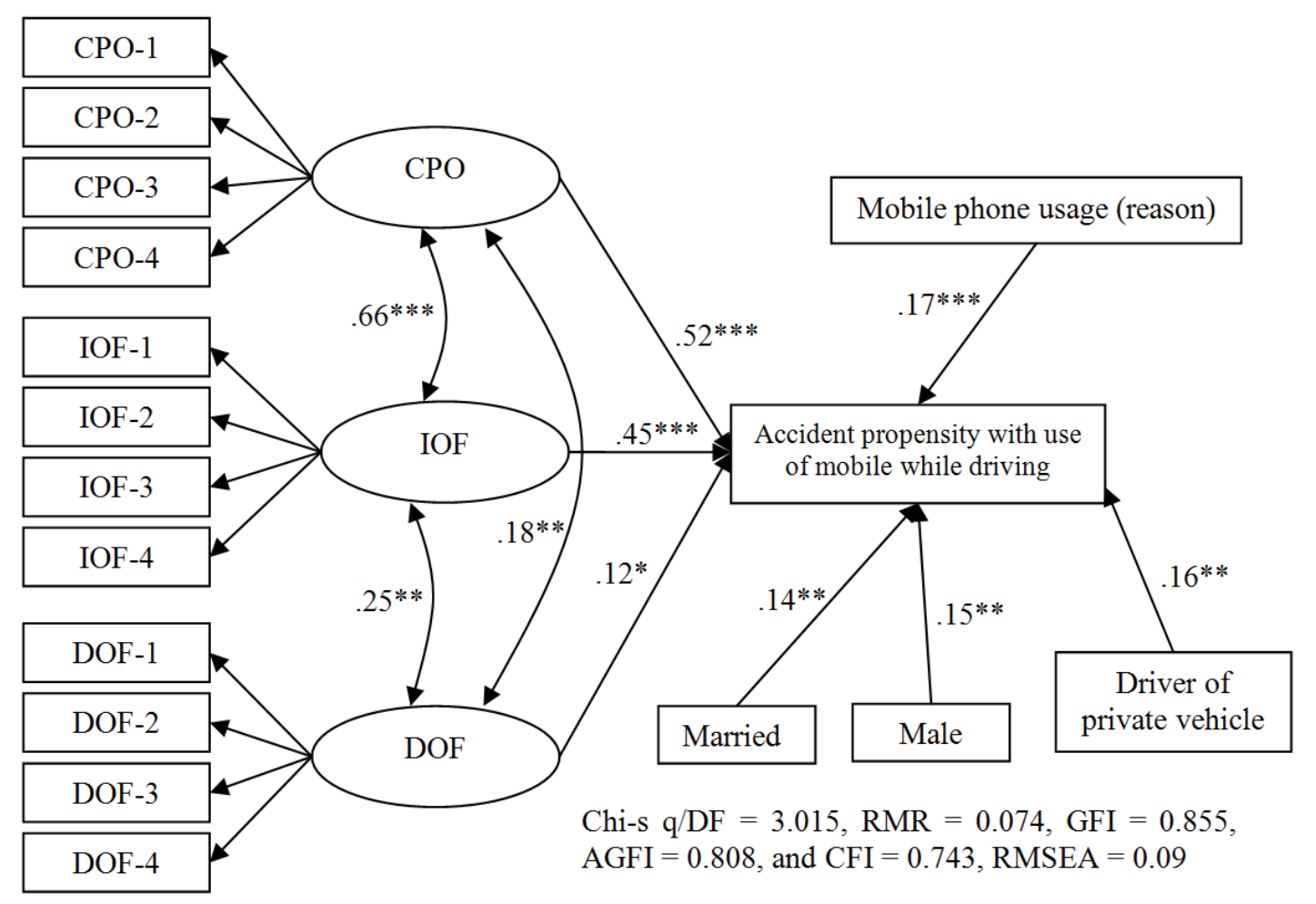

$\left(* * *\right.$ significant at $1 \%, *^{*}$ significant at $5 \%, *$ significant at $10 \%$ )

Figure 3: Structural models of driver's distraction factors 
APPENDIX: Questionnaire Items

Part 1: Kindly choose appropriate option or write for each question

\begin{tabular}{|c|c|}
\hline Q1) Age --------------- years & 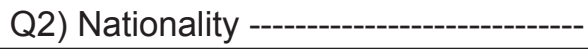 \\
\hline Q3) Gender & (1) Male (2) Female \\
\hline Q4) Marital status & (1) Single (2) Married \\
\hline Q5) Education & $\begin{array}{l}\text { (1) Below secondary } \\
\text { (2) Bachelor } \\
\text { (3) Master or above }\end{array}$ \\
\hline Q6) Profession & $\begin{array}{l}\text { (1) Student } \\
\text { (2) Employee } \\
\text { (3) Business man } \\
\text { (4) Others }\end{array}$ \\
\hline Q7) Type of vehicle drive & $\begin{array}{l}\text { (1) Private car } \\
\text { (2) Taxi } \\
\text { (3) Bus } \\
\text { (4) Truck } \\
\text { (5) Others }\end{array}$ \\
\hline Q8) How much time do you drive per day? & $\begin{array}{l}\text { (1) } 15-30 \text { minutes } \\
\text { (2) 1-2 hours } \\
\text { (3) 3-4 hours } \\
\text { (4) more than } 4 \text { hours }\end{array}$ \\
\hline Q9) Driving experience (years) & $\begin{array}{l}\text { (1) } 1-2 \text { years } \\
\text { (2) } 3-4 \text { years } \\
\text { (3) } 5-6 \text { years } \\
\text { (4) above } 6 \text { years }\end{array}$ \\
\hline
\end{tabular}

Part 2: Kindly choose appropriate option from five point scale against statement

\begin{tabular}{|c|c|c|}
\hline$\#$ & Description & Scale \\
\hline 1 & Do you perform other activities while driving? & \multirow{16}{*}{$\begin{array}{c}\text { Never } \\
\text { Rarely } \\
\text { Sometimes } \\
\text { Very often } \\
\text { Always }\end{array}$} \\
\hline 2 & How often you use your hand to make phone calls while driving? & \\
\hline 3 & $\begin{array}{l}\text { How often you use headphones or Bluetooth to make phone calls while } \\
\text { you driving? }\end{array}$ & \\
\hline 4 & Do you text while driving? & \\
\hline 5 & Do you adjust the tape recorder or $\mathrm{mp} 3$ while driving? & \\
\hline 6 & Do you eat or drink while driving? & \\
\hline 7 & Do you smoke while you are driving? & \\
\hline 8 & Do you interact with others in the vehicle while driving? & \\
\hline 9 & Do you focus on advertising in the road while driving & \\
\hline 10 & Does bright light of front vehicle disturb you? & \\
\hline 11 & Do you get disturbed when there are children sitting in the back seat? & \\
\hline 12 & How often you notice other drivers using mobile phone while driving? & \\
\hline 13 & Do you get disturbed when a police car or ambulance overtakes you? & \\
\hline 14 & Do you check social media while you driving? & \\
\hline 15 & Does rain affect on your driving behaviour? & \\
\hline 16 & How often you observe animals crossing the road? & \\
\hline
\end{tabular}


Part 3

\begin{tabular}{|c|c|c|}
\hline 1 & \multicolumn{2}{|c|}{$\begin{array}{c}\text { What do you think about the main reason of accident in Oman? (choose only one) } \\
\text { Over speeding, Use of phone, Fatigue or stress, Wrong overtaking, Others }\end{array}$} \\
\hline 2 & $\begin{array}{c}\text { Use of mobile phone while driving increases the } \\
\text { chance of having an accident }\end{array}$ & $\begin{array}{c}\text { Strongly agree, agree, neutral, disagree } \\
\text { and strongly disagree }\end{array}$ \\
\hline 3 & $\begin{array}{c}\text { I believe that availability of a good quality public } \\
\text { transport system would help in reducing } \\
\text { the accident rate in Oman }\end{array}$ & (1)Yes \\
\hline 4 & $\begin{array}{c}\text { Have you ever experience an accident while you } \\
\text { are using mobile during driving }\end{array}$ & (2) No \\
\hline 5 & $\begin{array}{c}\text { Do you know any accident case while other } \\
\text { drivers are using mobile during }\end{array}$ & \\
\hline
\end{tabular}

\section{REFERENCES}

1. Islam, M.M., Al-Hadhrami, A.Y.S. (2012). Increased Motorization and Road Traffic Accidents in Oman. Journal of Emerging Trends in Economics and Management Sciences, vol. 3, no. 6, 907-914.

2. World Health Organization (WHO). Global status report on road safety 2015 , Geneva.

3. Facts and figures, Directorate of traffic and safety, Royal Oman Police (ROP), 2016.

4. Al-Reesi, H, Al-Maniri, A., Al-Adawi, S., Davey, J., Armstrong, K., Edwards, J. (2016). Prevalence and characteristics of road traffic injuries among young drivers in Oman, 2009-2011. Traffic Injury Prevention, vol. 17 , no. $5,480-487$. https://doi.org/10.1080/ 15389588.2015.1107679

5. Belwal, R., Belwal, S., Al-Quraini, A., (2015). Road Traffic Accidents (RTAs) and road safety in Oman: an analysis of people's perception towards the causes. Advances in Transportation Studies: an International Journal Section B, vol. 37, 105-118.

6. Regan, M.A., Young, K.L., Johnston, I.J. (2005). Monash University Accident Research Centre Submission to the Parliamentary Road Safety Committee: Inquiry into Driver Distraction. Monash University Accident Research Centre, Clayton, Victoria.

7. Yannis, G., Roumpas, L., Papadimitriou, E. (2016). Mobile phone use, speed and accident probability of young drivers. Advances in Transportation Studies: an International Journal Section B, vol. 39, 51-68.

8. Yannis, G. (2013). Review of distracted driving factors. Proceedings of 13th WCTR, July 15-18, 2013 - Rio de Janeiro, Brazil.

9. Yannis, G., Papadimitriou, E., Bairamis, C., Sklias V. (2011). Is it risky to talk, eat or smoke while driving? Findings from a driving simulator experiment". Proceedings of the third International Conference on Road Safety and Simulation, Indianapolis, September 2011.
10. Foss, R.D., Goodwin, A.H. (2014). Distracted Driver Behaviours and Distracting Conditions Among Adolescent Drivers: Findings From a Naturalistic Driving Study. Journal of Adolescent Health, vol. 54, no. 5, S50-S60. https://doi.org/10.1016/j. jadohealth.2014.01.005

11. Simons-Morton, B.G., Guo, F., Klauer, S.G., Ehsani, J.P., Pradhan, A.K. (2014). Keep Your Eyes on the Road: Young Driver Crash Risk Increases According to Duration of Distraction. Journal of Adolescent Health, vol. 54, no. 5, S61-S67. doi: 10.1016/j.jadohealth.2013.11.021.

12. Engelberg, J.K., Hill, L.L., Rybar, J., Styer, T. (2015). Distracted driving behaviours related to cell phone use among middle-aged adults. Journal of Transport \& Health, vol. 2, no. 3, 434-440. https:// doi.org/10.1016/j.jth.2015.05.002

13. Al-Azri, M., Al-Reesi, H., Al-Adawi, S., Al-Maniri, A., Freeman, J. (2017). Personality of young drivers in Oman: Relationship to risky driving behaviours and crash involvement among Sultan Qaboos University students. Traffic Injury Prevention, vol. 18, no. 2, 150-156. doi: 10.1080/15389588.2016.1235269

14. Javid, M.A., Faraz, N.S. (2017). Understanding the behaviour of young drivers in relation to traffic safety aspects in Lahore. Pakistan Journal of Science, vol. 69, no.1, 144-149.

15. Tavakol, M., Dennick, R. (2011). Making Sense of Cronbach's Alpha. International Journal of Medical Education, vol. 2, 53-55. http://dx.doi.org/10.5116/ ijme.4dfb.8dfd

Paper submitted: 25.02.2018.

Paper accepted: 04.05.2018.

This is an open access article distributed under the CC BY-NC-ND 4.0 terms and conditions. 